\title{
Effect of oxytetracyclin and florfenicol on growth, feed utilization and residual measurements in Nile tilapia, oreochromis niloticus
}

\author{
M. A. Soltan; *A. I. M. El-Sayed*; M. S. Hassan**; M. Ibrahim*; Rokaya, M. Hussein***; Mona G. \\ Mohamed*** \\ * Faculty of Agriculture Moshtohor, Benha University \\ ** National Institute of Ocenography and fishries Cairo \\ *** National organization for Drug control and Research (NODCAR)
}

\begin{abstract}
The present work aimed to study the effect of different doses of oxytetracyclin $(0,40,80,120 \mathrm{mg} / \mathrm{kg}$ basal diet) and florfenicol, $(0,7.5,15,22.5 \mathrm{mg} / \mathrm{kg}$ basal diet) on growth performance, feed utilization and residual measurements in Oreochromis niloticus. The results revealed that the dose $40 \mathrm{mg}$ oxytetracycline $/ \mathrm{kg}$ basal diet caused the highest final Body weight, weight gain, specific growth rate, condition factor, moreover it improved feed conversion ratio compared with other doses of oxytetracycline, florfenicol and control group. Also the best protein efficiency was recorded by fish fed the diet $40 \mathrm{mg}$ oxytetracycline $/ \mathrm{Kg}$ basal diet. The results of determination of oxytetracycline and florfenicol in fish muscle after 10, 21 days were negative results but after 3 months the results were positive and the lowest concentration of antibiotic by fish fed the diet $40 \mathrm{mg}$ oxytetracycline $/ \mathrm{kg}$ basal diet.
\end{abstract}

Key words: Feed utilization, florfenicol, Oreochromis niloticus, oxytetracycline residue.

\section{Introduction}

The antibiotics oxytetracycline and florfenicol hve been used in fish culture to control or treat bacterial infections (Nusbaum and shotts, 1981). Oxytetracycline resulted significantly changes in weight, length and condition factor but no significantly different in feed intak, feed conversion ratio in catfish as reported by Sanchez Martinez et al. (2008). Gaikowski et al. (2003) indicated that the using florfenicol in feed caused no mortalities and different in growth but decreased feed consumption. Roberts (1978) mentioned that 4 weeks at least necessary for the clearance of the antibiotic from the treated fish tissues. Also, Feng et al. (2008) found that the concentration of florfenicol in tissues of fresh water were higher than in sea water tilapia.

Therefore, the aim of the present study is to investigate the effect of different levels of oxytetracycline and florfenicol on the growth, feed utilization and residual measurements in Nile tilapia

\section{Materials and methods}

The experimental work of the present study was carried out at the laboratory of fish nutrition, faculty of Agriculture, Moshtohor, Benha University. The experimental fish were obtaind from El-Manzala hatchery, Al-Dakahlya Governorate. The experimental fish were transported in 50 liter plastic bags filled with water and oxygen to the laboratory, and after arrival to the laboratory fish were adapted and distributed randomly into 7 groups and each groups was replicated in three aquarium and each aquaria was stoked with 30 fish with intial weight of $7 \pm 0.66 \mathrm{~g}$.

The experiment started on May 2011 and lasted in August of the same year (90 days). The oxytetracycline and florfenicol were added to the basal diet (as medicated feed during the whole experimental period) as follow:

Group 1: control group (Kept without treatment).

Group 2: administrated subtherapeutic 40mg oxytetracyclinc/kg basal diet.

Group 3: administrated therapeutic $80 \mathrm{mg}$ oxytetracyline $/ \mathrm{kg}$ basal diet.

Group 4: administrated supertherapeutic 120mg oxytetracyline $/ \mathrm{kg}$ basal diet.

Group 5: administrated subtherapeutic $7.5 \mathrm{mg}$ florfenicol / $\mathrm{kg}$ basal diet.

Group 6: administrated therapeutic $15 \mathrm{mg}$ florfenicol / kg basal diet.

Group 7: administrated supertherputic $22.5 \mathrm{mg}$ florfenicol / $\mathrm{kg}$ basal diet.

Composition and chemical analysis of the basal diet used in the experiment are presented in Table 1.

Fish were given the experimental diets at a daily rate of $3 \%$ of total biomass till the end of experimental period. Fish were fed on the experimental diets at the rates mentioned above 6 day/week (twic daily at 9.00 am and $3.00 \mathrm{pm}$ ).

The fish were weighted every two weeks. The total weight of 30 fish were recorded and immediately returned to the aquaria and the feed amount for the next two weeks for each aquarium was adjusted according to the new weight (Windell 1971). 
Body weight gain and specific growth rate were accounted according to (Jauncey and Ross, 1982) as follow:

Weight gain = final fish weight $(\mathrm{g})-$ initial fish weight $(\mathrm{g})$.

Specific Growth Rate (SGR): =

$\frac{\mathrm{LnW} 2-\mathrm{LnW} 1}{\mathrm{t}} \times 100$

Where $\mathrm{Ln}=$ the natural $\log$; W1=first fish weight; $\mathrm{W} 2=$ the following fish weight in "grams" and $\mathrm{t}=$ period in days.

Also data from 10 fish were obtained to calculate the condition Factor by using the following formula (Weatherley and Gill, 1987).

Condition factor $(k)=\frac{W}{L_{3}} \quad \times 100$

$\mathrm{W}=$ weight of fish in grams.

$\mathrm{L}=$ total length of fish in $\mathrm{Cm}$.

Feed conversion ratio FCR $=$ feed intake $(\mathrm{g}) /$ weight gain $(\mathrm{g})$.

(Desiliva and Anderson, 1995).

Protein efficiency ratio PER = weight gain $(\mathrm{g}) /$ protein ingested $(\mathrm{g})$

Survival rate (SR) calculated according to Harrel et al. (1990).

SR $\frac{\text { nt }}{\text { no }} \times 100$

$\mathrm{nt}=$ total number of fish survived in a aquarium at the end of the experiment.

no $=$ total number of fish in a aquarium at the start of the experiment.

Determination of oxytetracycline and florfenicol residues in tissues of tilapia fish After 10, 21 days using HPLC according to McNeil et al. (1996). The results were negative for all doses and at the end of experiment after 3 months using microbiological assay according to Heitzman (1994). The results were positive for all doses of oxytetracycline and florfenicol.

Statistical analysis of the obtained data was analyzed according to SAS (1996) by adopting the following model.

Where:

$$
Y i j=U+\alpha_{i}+e i j
$$

Yij $=$ The observation on the $\mathrm{ij}$ fish eaten the $i^{\text {th }}$ diet.

$\mathrm{U}=$ overall mean

$\alpha_{i}=$ the effect of $\mathrm{J}^{\text {th }}$ treatment.

Eij=random error assumed to be independently and randomly distributed $\left(0, \delta^{2} \mathrm{e}\right)$.

Differences between means were tested for significance according to duncan's multiple rang test as described by Duncan (1955).

\section{Results and discussion}

Body weight (BW) and Body length (BL)
Results in Table 2 indicated that the dose $40 \mathrm{mg}$ oxytetracycline/kg basal diet resulted the highest body weight, condition factors compared with control group and other doses of oxytetracycline while the dose $22.5 \mathrm{mg}$ florfenicol/ $\mathrm{kg}$ basal diet caused the highest body weight, body length compared with control group and doses of florfenicol.

\section{Weight gain (WG) and specific growth rate (SGR):}

Results in Table 3 show that the highest weight gain value and the highest specific growth rate value was recorded by fish fed on the diet contained subtherapeutic dose $40 \mathrm{mg}$ oxytetracyclin $/ \mathrm{kg}$ basal diet compared with control group and other doses of oxytetracycline and florfenicol.

\section{Feed utilization:}

With regard to the effect of oxytetracycline and florfenicol doses on feed intake, feed conversion ratio and protein efficiency ratio of Nile tilapia, the results in Table 4 show that the highest feed intake (29.02) was recorded for fish fed diet $22.5 \mathrm{mg}$ florfenicol/kg basal diet compared with control group and other doses of oxytetracycline and florfenicol. The best value of feed conversion ratio (1.95) and protein (1.72) were observed with the dose $40 \mathrm{mg}$ oxytetracycline / $\mathrm{kg}$ basal diet compared with control group and other doses of oxytetracycline and florfenicol. These results are in agreement with those of Brocklebank et al., (1993) and Eid et al., (2005) who found that the addition of the antibiotics oxytetracycline to the diet enhanced growth (Weight and length).

Soltan et al. (2006) found that the addition of flumequine at does $10 \mathrm{mg} / \mathrm{kg} \mathrm{B.W/day} \mathrm{in} \mathrm{diets}$ increased weight gain and specific growth rate.

Sanchez Martinez et al. (2008) reported that condition factor was significantly higher $(\mathrm{P}<0.05)$ in the oxytetracycline treated fish. On the other hand Conaver and Sheehan (1999) found no significant difference in length, weight, condition factor after 31 weeks in the oxytetracycline treated fish.

Detection of oxytetracycline and florfenicol residues:

The results of determination of oxytetracycline and florfenicol residues in tissues showed that after 10, 21 days all samples revealed negative results (Table 5). While after 90 days (at the end of experiment) all samples were positive (Table 5). The dose $40 \mathrm{mg}$ oxytetracycline $/ \mathrm{kg}$ basal diet and $7.5 \mathrm{mg}$ florfenicol/kg basal diet caused lowest value in residue in the muscle of fish compared with control group and other doses.

These results are inagreement with Jose Malvisi et al. (1996) who found that the fish treated by 7.5 $\mathrm{mg}$ oxytetracycline $/ \mathrm{kg}$ feed the residual of oxytetracycline in muscle was lower than of skin and 
liver. Also Gaikowski et al. (2010) found that the fish fed the diet $15 \mathrm{mg}$ florfenicol $/ \mathrm{kg}$ of body weight for 12,21 days the florfenicol rapidly eliminated from tilapia fellet after withdrawal.
On the other hand Soltan et al. (2006) found that no residual of flumequine after 3 months. Azab et al. (2003) detected flumequine residues in fish tissues until 10, 20 days.

Table 1. Composition and chemical analysis of basal diet.

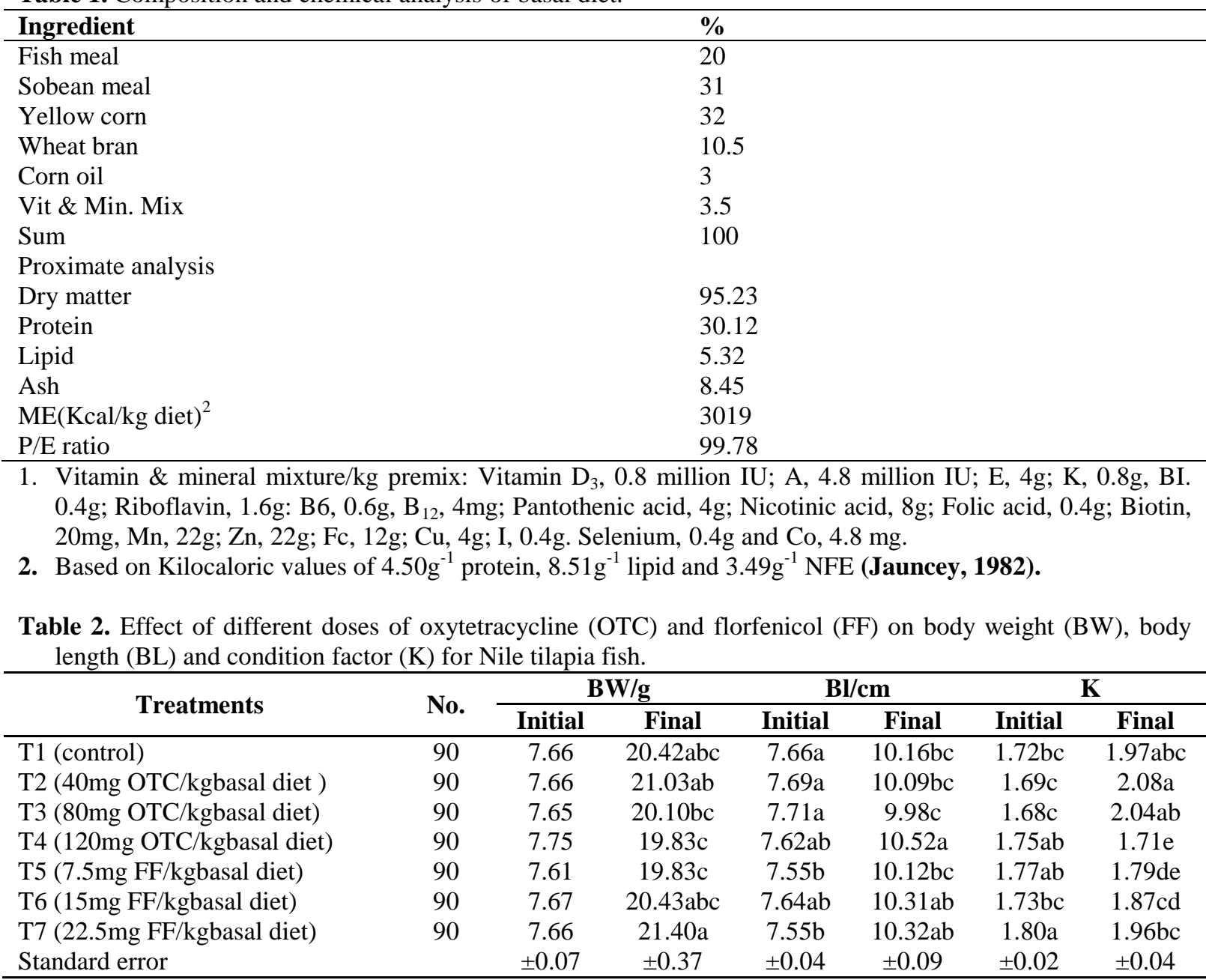

$*$ Data are presented means \pm standard error (SE).

** Means followed by different letters in each column are significantly $(\mathrm{P}<0.05)$ different.

Table 3. Effect of different doses of oxytetracycline (OTC) and florfenicol (FF) on weight gain (WG) and specific growth rate (SGR) of Nile tilapia fish.

\begin{tabular}{lccc}
\hline \multicolumn{1}{c}{ Treatments } & No. & WG $(\mathbf{g})$ & SGR (\%/day) \\
\hline T1 (control) & 3 & 12.77 & 1.09 \\
T2 (40mg OTC/kg basal diet) & 3 & 13.38 & 1.13 \\
T3 (80mg OTC/kg basal diet) & 3 & 12.44 & 1.07 \\
T4 (120mg OTC/kg basal diet) & 3 & 12.08 & 1.04 \\
T5 (7.5mg FF/kg basal diet) & 3 & 12.22 & 1.04 \\
T6 (15mg FF/kg basal diet) & 3 & 12.76 & 1.03 \\
T7 (22.5mg FF/kg basal diet) & 3 & 12.30 & 1.05 \\
Standard error & 3 & \pm 0.58 & \pm 0.03 \\
\hline
\end{tabular}

* Data are presented as means \pm standard error $(\mathrm{SE})$. 
Table 4. Effect of different doses of oxytetracycline (OTC) and florfenicol (FF) on feed intake (FI), feed conversion ratio (FCR) and protein efficiency ratio (RER) of Nile tilapia fish.

\begin{tabular}{lcccc}
\hline Treatments & No. & FI (g/fish) & $\begin{array}{c}\text { FCR } \\
\text { g feed/g gain }\end{array}$ & $\begin{array}{c}\text { PER g gain/g CP } \\
\text { intake }\end{array}$ \\
\hline T1 (control) & 3 & 26.44 & 2.07 & 1.61 \\
T2 (40mg OTC/kg basal diet) & 3 & 26.09 & 1.95 & 1.72 \\
T3 (80mg OTC/kg basal diet) & 3 & 27.35 & 2.21 & 1.54 \\
T4 (120mg OTC/kg basal diet) & 3 & 25.95 & 2.15 & 1.55 \\
T5 (7.5mg FF/kg basal diet) & 3 & 25.90 & 2.12 & 1.57 \\
T6 (15mg FF/kg basal diet) & 3 & 27.29 & 2.15 & 1.56 \\
T7 (22.5mg FF/kg basal diet) & 3 & 29.02 & 2.45 & 1.42 \\
Standard error & & \pm 1.05 & \pm 0.16 & \pm 0.10 \\
\hline
\end{tabular}

* Data are presented as means \pm standard error (SE).

Table 5. oxytetracycline and florfenicol residues in fish muscle after ten days, twenty one days and 90 days.

\section{Fish treatment}

Concentration of antibiotic residue $\mu \mathrm{g} / \mathrm{g}$

T1 control

T2 40mg OTC/kg basal diet

T3 80mg OTC/kg basal diet

T4 120mg OTC/kg basal diet

T5 7.5mg FF/kg basal diet

T6 $15 \mathrm{mg} \mathrm{FF} / \mathrm{kg}$ basal diet

T7 22.5 FF/kg basal diet

\section{Conclusion}

This study recommend the addition of oxytetracycline to Nile tilapia diets at a dose of 40mg oxytetracycline $/ \mathrm{kg}$ basal diet as prophylactic and improved growth, protein efficiency, feed utilization and lowest values for antibiotic residues also the dose $7.5 \mathrm{mg}$ florfenicol/ $\mathrm{kg}$ basal diet whereas caused lowest values for anbiotic residues compared with other doses of florfenicol.

\section{References}

Azab, M.E, Fathalla, S.I; Soltan, M.A and Radwan H.A (2003): Effect of flumequine on growth and chromosomes of Nile Tilapia (Orochromes niloticus). $3^{\text {rd }}$ Int. Sci. Conf. Mansoura.

Brocklebank, J.R; Evelyn, T.P. Speare, D.J; and Armstrong, R.D. (1993). Rickettsial septicemia in farmed Atlantic and Chinook salmon in British Columbia: clinical presentation and experimental transmission. Canadian-Veterinary-Journal. 34(12): 745-748.

Conover, G.A; and Sheehan, R.J. (1999). Survival, growth and mark persistence in juvenile black crappies marked with fin clips freeze brands, or oxytetracycline. North. American. Journal-ofFisheries-Management. 19(3); 824-827.

Desilva, S.S. and Anderson, T.A. (1995): Fish nutrition in aquaculture. Chapman edaw of Hall, London.

Duncan, D.B. (1955): Multiple range and multiple F. test. Biometrics, $11: 1-24$.

\begin{tabular}{lc} 
and 21 days & After 90 days \\
\hline 0 & 0.00 \\
0 & 15.61 \\
0 & 18.91 \\
0 & 22.81 \\
0 & 19.72 \\
0 & 24.63 \\
0 & 38.86
\end{tabular}

Eid, A.E; Al-Danasoury, M.A; El-Gamal, R.M; and El-Aidy, E.S. (2005). Effect of different dietary protein levels and oxytetracycline on intestinal bacterial load of Nile Tilapia fingerlings (oreochromis niloticus). Egyptian-Journal of Agricultureal Research, 83(3): 1383 - 1396.

Feng, J.BV, Xiao, P.J. and Liu, D.L. (2008): Tissue distribution and elimination of florfenicol in Tilapia (oreochromis niloticus x $O$. caureus) after a single oral administration in fresh water and Sea water at $28^{\circ} \mathrm{C}$. Aquaculture 276-29-35.

Gaikowski, M.P; Wolf. J.C.; Endris, R.G.; and Gingerich, W.H. (2003): Safety of Aquaflor (florfenicol; 50\% type a medicated, article, administered in feed to channel catfish, Lctalurus punctatus. Toxicologic pathology 30:684-697.

Gaikowski, M.P; Mohammad, M; Phillip, C; Jeffery, R. and Meinertz, S. (2010): Depletion of florfenicol amine, Marker residue of florfenicol, from the edible fillet of Tilapia $O$. niloticus x $O$. aureus) following florfenicol administration in feed. Aquaculture, 301:1-6.

Harrel, R.M.; Kerby, J.H.; and Minton, R.V. (1990): Culture and propagation of striped bass and its hybrids striped bass Committee, Southern Division, American Fisheries Society, and Belhesda Maryland.

Heitzman R.J. (1994): Residues in food producing animals and their products. Veternary drug Residues Black well science. Eur 15127-EN.

Jose Malvisi, G.D., Paola, A.F., and Giorgio, G. (1996). Tissue distribution and residue depletion of oxytetracycline in sea bream hematopoietic tissue of a marine fish following in Vivo 
exposure to genotoxic carcinogens. Mutat. Res. Nov., 172(2): 165-175.

Jauncey, K. (1982): The effect of varying dietary protein level on the growth, feed conversion protein utilization and body composition of Juvenile Tilapia (Sarotherdou messambicus). Aquaculture, 27:43-54.

Jauncey, K. and Ross, B.R. (1982): A guide to Tilapia feeds and feeding. Institute of Aquaculture, University of Stirling, FKA, Scotland, V.K.L;9:68.

McNeil, J.D. Martz, V.K. Korsrude, G., Salisbury, D.C., Oka, H. Epstein, R.L. and Barners, G.J. (1996): Chlorotetracycline, oxytetracycline, and tetracycline in edible animal tissue, liquid chromatographic method : collaborative study. J. AOAC, 79(2) 405-417.

Nusbaum, DE and Shotts, E.B. (1981): Absorption of selected antimicrobic drugs from water by channel catfish, Ictalurus punctatus, can J. fish. Aquatic Sci 38: 993-996.

Roberts, R.J. (1978): Therapy of fish diseases. Fish pathology. Bailliere Tindall, a division of cass
112TD, London, Macmillan publishing CO.INC: New York, 271-275.

Sanchez. Martinez, J.G.; Perez Castaneda, R.; Rabago. Castro, J.L.; Aguirre. Guzman, G; and Vazquez. Sauceda, M.L. (2008). A preliminary study on the effects on growth, condition, and feeding indexes in channel catfish lctalurus punctatus, after the prophylactic use of potassium permanganate and oxytetracycline. Journal-ofthe- World-Aquaculture. Society. 39(5): 664-670.

SAS, (1996): SAS procedure guide "version 6.12 Ed". SAS Institute Inc., Gary, NC, USA.

Soltan, M.A., El-Sayed, A.I., Hassanin, L.A., Iraqi, M.M., Hussanin, R.M., Mohamed, M.G. (2006): Effect of flumequine on the growth residual measurements and chromosomal aberrations in Tilapia Fish. J. Drug Res. Egypt, Vol. 27, No. 12: 109-117.

Weatherley, A.H. and Gill, H.S. (1987): The biology of fish growth Edited by Academic press London, PP. 18.

Windell, J.T. (1971): Estimating food consumption rates of fish population. In Methods of fish production in fresh waters (Ed. By Bagenal, T.). 


\section{تأثير الأوكسى تتراسيكلين والفلورفينيكول على النمو والاستفادة من الغذاء وقياسات المتبقى فى البلطى النيلى}

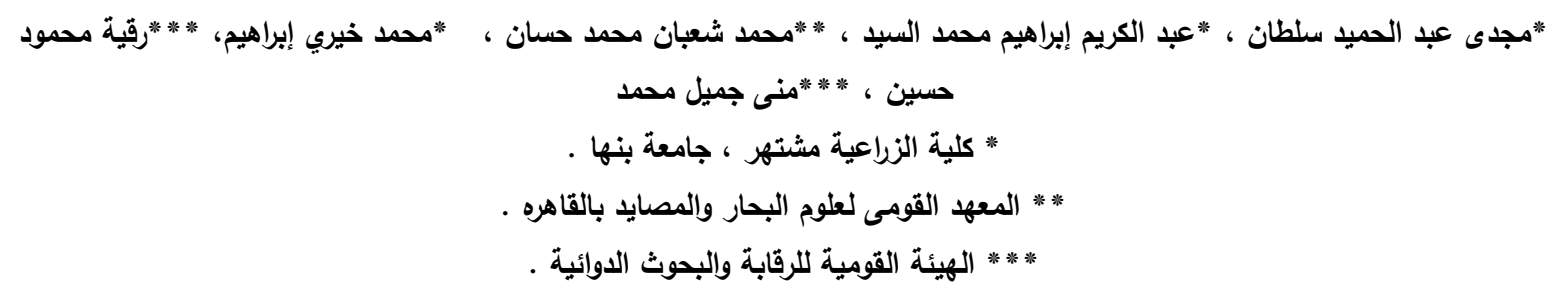

تهدف هذه التجربة إلى دراسة تأثير إضافة جرعات مختلفة من المضاد الحيوي الأوكسى تتراسيكلين وهى (0 ، 40 ، 80 ، 120 ملجم/كجم

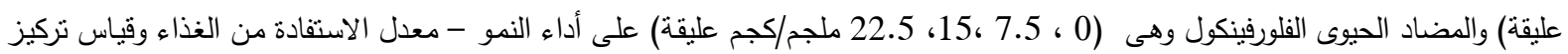
المضاد الحيوى فى أنسجة البلطى النيلى بعد انتهاء مدة التجربة. أظهرت النتائج أن الجرعة 40 ملجم أوكسى نتراسيكلين/كجم عليقة كان لها تأثنير معنوى على زيادة وزن الجسم النهائى - معدل النمو

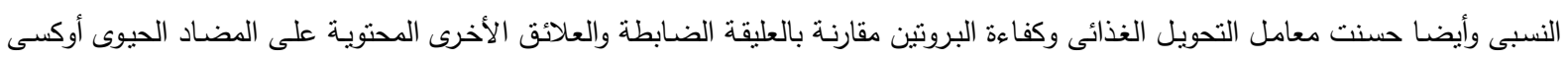
تتراسيكلين والفلورفينكول . وبالنسبة لتقدير متبقيات المضاد الحيوى أوكسى نتراسيكلين والفلورفينكول فى أنسجة الأسماك بعد انتهاء التجربة (بعد 90 يوم) فقد وجد أن الجرعة 40ملجم أوكسى تتراسيكلين/كجم عليقة والجرعة 7.5 ملجم فلورفينكول / كجم عليقة قد تركت بقايا مضاد حيوى ولكن بنسبة أقل عن باقى ولى

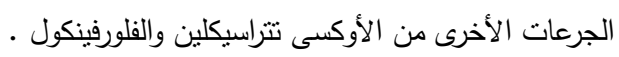
لذا توصى هذه الدراسة باستخدام جرعات من المضاد الحيوى أوكسى تتراسيكلين 40 ملجم/كجم عليقة ، حيث أدت إلى تحسين كفاءة النمو

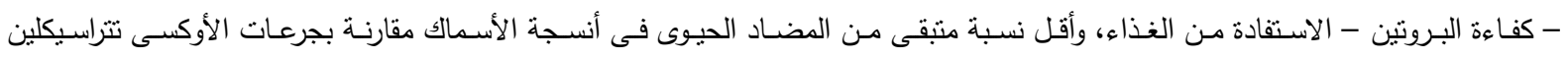
والفلورفينكول ، والجرعة 7.5 ملجم فلورفينكول/كجم عليقة حيث أحدثت أقل نسبة من متبقى المضاد الحيوى فى أنسجة الأسماك مقارنة بالجرعات الأخرى من الفلورفينكول . 